\title{
Fracture Resistance of Teeth Subjected to Internal Bleaching and Restored with Different Procedures
}

\author{
Roseli Aparecida AZEVEDO \\ Yara Teresinha Correa SILVA-SOUSA \\ Aline Evangelista SOUZA-GABRIEL \\ Danielle Cristine Furtado MESSIAS \\ Edson ALFREDO \\ Ricardo Gariba SILVA
}

Dental School, University of Ribeirão Preto, Ribeirão Preto, SP, Brazil

\begin{abstract}
This study evaluated the fracture resistance of teeth submitted to internal bleaching and restored with different procedures. Forty maxillary incisors were endodontically treated and assigned to 4 groups ( $n=10)$ : G1- restored with composite resin (CR), G2- bleached with hydrogen peroxide (HP) and restored with CR, G3- restored with CR and fiberglass posts (CR + posts) and G4- bleached and restored with CR + posts. HP was applied in the buccal surface and pulp chamber 3 times at each one of 2 sessions with an interval of 7 days between them. Additional 10 sound incisors were subjected to fracture strength test (gold standard). The fracture strength (kN) was determined in an Instron machine. Data were analyzed by ANOVA and Tukey-Kramer test $(\alpha=0.05)$. The untreated teeth (gold standard) showed the highest $(\mathrm{p}<0.05)$ fracture strength $(0.43 \pm 0.16)$. Teeth restored with $\mathrm{CR}(\mathrm{G} 1)$ without internal bleaching had the lowest $(\mathrm{p}<0.05)$ fracture strength $(0.23 \pm 0.11)$. Teeth bleached and restored with $\mathrm{CR}(\mathrm{G} 2)(0.26 \pm 0.10)$, restored with CR + posts ithout internal bleaching (G3) $(0.31 \pm 0.17)$ and, bleached and restored with CR + posts (G4) $(0.33 \pm 0.12)$ had intermediate values, sometimes similar to the group with the highest value, sometimes similar to the group with the lowest value. In conclusion, as far as the fracture strength is concerned, teeth subjected to internal bleaching can be restored with composite resin alone, as the use of posts in these teeth did not increase their resistance.
\end{abstract}

Key Words: bleaching, fracture resistance, fiber post, composite resin.

\section{INTRODUCTION}

The mechanism of tooth bleaching relies on a redox reaction in which the release of free oxygen after hydrogen peroxide (HP) degradation recovers the chromatic alteration of dental tissues (1). Light sources may be used to activate the bleaching agents, intensify the reaction and accelerate the whitening process (2).

The adverse effects of the bleaching procedure are attributed to the presence of HP, which can modify the microhardness (3) and elasticity modulus (4) of the dental tissues. These alterations may be related to the reduction of the organic components of dentin (5) and to the changes in tissue morphology (6), which can influence the fracture resistance of bleached teeth (7-9). Such problem is even more critical in endodontically treated teeth, which present some degree of structural weakness (7). In this context, materials and restorative techniques may reinforce the remaining tooth structure. Adhesive restorative materials, mainly composite resins, have been used in the restoration and rehabilitation of root-filled teeth (10). Prefabricated posts may be used to restore severely destroyed teeth and those subjected to the bleaching process $(11,12)$.

However, the most indicated restorative procedure to recover the resistance of teeth subjected to endodontic treatment and to the action of bleaching agents is not well established. This in vitro study evaluated the fracture strength of teeth subjected to internal bleaching with $38 \% \mathrm{HP}$ and restored with different procedures.

\section{MATERIAL AND METHODS}

This study was approved by the Research Ethics 
Committee of the University of Ribeirão Preto, São Paulo, Brazil (Protocol number 144/08).

Fifty maxillary incisors stored in $0.1 \%$ thymol solution at $4{ }^{\circ} \mathrm{C}$ were selected. All teeth had straight roots, completely formed apexes, single canals, and no calcification or resorption, as confirmed radiographically. Forty teeth were used in the experimental groups and 10 teeth were not treated to be used as gold standard (control).

The 40 teeth in the experimental groups were subjected to endodontic treatment. After pulp chamber access, the working length was determined by subtracting $1 \mathrm{~mm}$ from the root length using a \#10 K-file (Maillefer, Ballaigues, Switzerland). Instrumentation was performed with K3 instruments (SybronEndo, Glendora, CA, USA). During this process, root canals were irrigated with $2 \mathrm{~mL}$ of $1 \%$ sodium hypochlorite between each file, followed by final irrigation with EDTA for 5 min. Irrigation was subsequently done with $10 \mathrm{~mL}$ of distilled water, and the canals were dried with absorbent paper points (DentsplyHerpo, Petrópolis, RJ, Brazil). The root canals were filled by thermomechanical condensation of gutta-percha points (Tanari, Manacapuru, AM, Brazil) and AH Plus cement (Dentsply DeTrey, Konstanz, Germany) with McSpadden instruments (Moyco Union Broach, York, PA, USA). Radiographs were taken to verify the quality of the obturation and teeth were stored at $37^{\circ} \mathrm{C}$ for $72 \mathrm{~h}$.

The endodontically treated teeth were distributed into 4 groups $(n=10)$ according to the bleaching treatment and restorative procedure: G1- restored with composite resin, G2-bleached with HP and restored with composite resin, G3- restored with composite resin and fiberglass posts and G4- bleached with HP and restored composite resin and fiberglass posts.

The bleached teeth (G2 and $\mathrm{G} 4)$ received a glass ionomer cement (MaxxionR; FGM, Dentscare Ltda, Joinville, SC, Brazil) 3-mm-thick cervical barrier at the cementoenamel junction. Teeth were stored at $37^{\circ} \mathrm{C}$ for $45 \mathrm{~min}$ to allow complete setting of the glass ionomer cement. They were then embedded in autopolymerizing acrylic resin (JET; Clássico Produtos Odontológicos Ltda., São Paulo, SP, Brazil) up to the cementoenamel junction, using a metallic rectangular matrix.

In $\mathrm{G} 2$ and $\mathrm{G} 4$, the bleaching procedure was performed with 38\% HP (Opalescence Xtra Boost; Ultradent Products Inc., South Jordan, UT, USA), activated by the LED-laser system (Brightness; Kondortech, São Carlos, SP, Brazil). The gel was applied to the buccal surface and in the pulp chamber followed by a $45 \mathrm{~s}$ application of light on both surfaces, followed by 5 -min interval and reapplication of light (9). The gel was aspirated and surfaces were irrigated with $1 \%$ sodium hypochlorite. This procedure was repeated 3 times in each session. Between sessions, teeth were stored for 7 days in artificial saliva at room temperature. Specimens (control and experimental groups) were temporarily sealed with white gutta-percha (DFL, Rio de Janeiro, RJ, Brazil) and non-eugenol temporary filling material (Coltosol; Vigodent, Rio de Janeiro, RJ, Brazil) before being placed in saliva. After bleaching, teeth from all groups were stored in artificial saliva at $37^{\circ} \mathrm{C}$ for 14 days.

Thereafter, teeth from G1 and G2 had the temporary seal and the cervical barrier removed with a diamond bur (Microdont Ltda, Socorro, SP, Brazil). The cavities were washed, dried with compressed air, etched with $37 \%$ phosphoric acid (3M ESPE, St. Paul, MN, USA) for $15 \mathrm{~s}$, washed with compressed water and dried with absorbent points. Single Bond adhesive system (3M ESPE) was applied according to the manufacturer's instructions and light activated for $10 \mathrm{~s}$ on the buccal surface and $10 \mathrm{~s}$ on the palatal face. The restorations were made at $3 \mathrm{~mm}$ below the cementoenamel junction with composite resin (Filtek Z250; 3M ESPE). The increments were light activated for $20 \mathrm{~s}$ and the last layer was light activated for $40 \mathrm{~s}$.

Teeth from G3 and G4 received reinforcement with intraradicular fiberglass posts Reforpost and Reforpin (Exacto; Ângelus, Londrina, PR, Brazil) and composite resin (Filtek Z250). The post spaces were prepared by removing $10 \mathrm{~mm}$ of gutta-percha with a heated plugger, retaining at least $5 \mathrm{~mm}$ of root filling at the apical level. The canal walls were prepared with a Largo bur \# 1 at low speed. The selected posts were cleaned with $70 \%$ alcohol and received a layer of silane (Ângelus) whose excess was removed with compressed air for $5 \mathrm{~s}$.

Root canals were washed with distilled water and dried with absorbent points. The adhesive system was applied into the canal and air-thinned for $10 \mathrm{~s}$. The Reforpost posts were cemented with a resin sealer (Rely $\mathrm{X}$; 3M ESPE) prepared according to the manufacturer's instructions. The sealer was inserted into the canal using a Lentulo bur \# 40 (Maillefer) and applied to the post surface. Then, the post was inserted into the canal in a single movement. Similarly, the Reforpin posts were placed inside the canal to fill the space. Sealer excess was removed and the material was light activated with a halogen lamp (Ultralux electronic; Dabi Atlante, 
Ribeirão Preto, SP, Brazil) for $30 \mathrm{~s}$ at each tooth face. After cementation, the remaining post length was cut and the final restoration of the palatal region was done with composite resin.

The specimens were subjected to the fracture strength test using a universal testing machine (Instron 4444; Instron Corp, Canton, MA, USA) $24 \mathrm{~h}$ after the restorative procedure. A device was used to standardize the position of the specimens, so that pressure could be applied at a $135^{\circ}$ angle with the long axis of the root. An increasing load was applied on the palatal surface of the tooth $(3.0 \mathrm{~mm}$ from the incisal region) with a rectangular round-tipped metal point. A crosshead speed of $1 \mathrm{~mm} / \mathrm{min}$ was applied until tooth fracture occurred. The moment of fracture was determined by a sudden decrease in force measurements in the testing machine.

Data were evaluated by ANOVA and TukeyKramer multiple-comparison test. All statistical procedures were performed using Graph Instat software (GraphPad Software Inc., San Diego, CA, USA) at a significance level of $5 \%$.

\section{RESULTS}

Means and standard deviation of strength $(\mathrm{kN})$ in each group are presented in Table 1. The ANOVArevealed significant difference $(p<0.05)$ among the groups. The untreated teeth (gold standard) showed the highest $(p<0.05)$ fracture strength, while teeth restored with composite resin without internal bleaching $(\mathrm{G} 1)$ showed the lowest $(\mathrm{p}<0.05)$ fracture strength. Teeth bleached

Table 1. Means and standard deviation of strength $(\mathrm{kN})$ required to fracture the teeth in each group.

\begin{tabular}{lc}
\hline Experimental groups & Mean $\pm \mathrm{SD}$ \\
\hline Untreated teeth (gold standard) & $0.43 \pm 0.16 \boldsymbol{\Delta}$ \\
Bleached/restored with CR + posts (G4) & $0.33 \pm 0.12 \boldsymbol{\Delta}$ \\
Restored with CR + posts (G3) & $0.31 \pm 0.17 \boldsymbol{\Delta}$ \\
Bleached/restored with CR (G2) & $0.26 \pm 0.10 \boldsymbol{\Delta}$ \\
Restored with CR (G1) & $0.23 \pm 0.11 \bullet \bullet$
\end{tabular}

$\mathrm{CR}=$ composite resin. Different symbols indicated statistically significant difference $(\mathrm{p}<0.05)$. and restored with composite resin (G2), restored with composite resin + posts without internal bleaching (G3) and, bleached and restored with composite resin + posts (G4) $(0.33 \pm 0.12)$ had intermediate values, sometimes similar to the group with the highest value, sometimes similar to the group with the lowest value.

The failure modes observed after the mechanical test are listed in Table 2. Overall, there was a predominance of radicular fracture in all groups.

\section{DISCUSSION}

In this study, the alignment of the specimens in the test machine was a critical point. The load cell was applied at a $135^{\circ}$ incidence angle, which is an approximate value of the inter-incisal angle formed between maxillary and mandibular incisors. However, variations of this angle have been reported in the literature (13). The methodology of the present study also used a rectangular round tip load for better distribution of the force along the dental crown $(9,14)$.

It has been demonstrated that the application of HP on enamel and dentin decreases their microhardness (3) and modulus of elasticity (4). HP at high concentration also produces morphological alterations in the dental surface (6), affect the intertubular and peritubular dentin (5) and causes structural alterations to the hydroxyapatite due to the ionic bonds that weaken its structure (15).

However, the findings of the present study

Table 2. Percentage of failure modes in the groups.

\begin{tabular}{llll}
\hline \multirow{2}{*}{ Experimental group } & \multicolumn{3}{l}{ Failure modes } \\
\cline { 2 - 4 } & CO & CR & RD \\
\hline Untreated teeth (gold standard) & 30 & 30 & 40 \\
Restored with CR (G1) & 10 & 40 & 50 \\
Bleached/restored with CR (G2) & 30 & 10 & 60 \\
Restored with CR + posts (G3) & & & \\
Bleached/restored with CR + posts (G4) & 30 & 30 & 40
\end{tabular}

$\mathrm{CR}=$ composite resin; $\mathrm{CO}=$ coronary $; \mathrm{CR}=$ coronoradicular; $\mathrm{RD}=$ radicular. 
showed that the bleaching treatment with $38 \%$ HP did not affect the fracture strength of the teeth. These results corroborate those of previous studies $(8,14,15)$ that evaluated the fracture strength of bleached teeth and verified that bleaching agents did not alter this property. On the other hand, Khoroushi et al. (16) verified that the fracture strength of endodontically treated teeth decreases after bleaching with different protocols of HP.

Another important consideration that might explain the results is related with the methodology. In the present study, the teeth were subjected only to two bleaching sections with a 7-day interval between them, as reported elsewhere (9). An increase in the number of bleaching sessions can increase the fracture strength.

The loss of tooth substance resulting from endodontic treatment might reduce the fracture strength of teeth $(11,17)$. However, in this study, the results obtained for most root-filled teeth were similar to those of the untreated teeth (gold standard). Therefore, it cannot be assumed that endodontic treatment, combined or not with internal bleaching, weakens the tooth structure.

Composite resin is an adequate material for the reconstruction of weakened teeth due to their inherent characteristics, such as lower degree of polymerization shrinkage, higher hardness, greater resistance to wear and compression $(10,11)$. The results of this study showed that teeth restored with composite resin and fiberglass posts had the same performance of those restored only with composite resin. According to Pontius and Hutter (17), endodontically treated teeth with adequate dentin thickness can be restored only with composite resin.

A previous study (12) showed that posts did not increase the fracture strength of teeth, but they improved the retention of the filling material in the remaining tooth structure. Another study (18) verified that fiber posts combined with composite resin increased tooth resistance to fracture, but those authors used weakenedroots, unlike the present study that tested fracture strength in teeth with crown, and hence had more dental structure.

Regarding the failure mode, there was a higher incidence of radicular fractures, which are considered unfavorable due to implications that can compromise tooth integrity. However, it should be noted that in the untreated group (gold standard), the unfavorable fractures (coronoradicular and radicular) occurred in $70 \%$ of samples. This result is probably derived from the in vitro methodology.

It is important to emphasize that the mineral loss of a bleached surface can be reduced by the use of low- concentration fluoride solution (19) or sodium ascorbate (16) between bleaching sessions. Further investigations are required to determine the fracture strength of teeth subjected to different bleaching procedures followed by fluoride treatment.

The findings of the present study and the researchbased evidence discussed indicate that bleaching of non-vital teeth can be considered as a viable procedure if safe clinical protocols are established. Additionally, it seems suitable to state that teeth subjected to internal bleaching can be restored with composite resin alone, as the use of posts in these teeth did not increase their resistance. Caution should be taken when using bleaching agents with high HP concentration for a long period.

\section{RESUMO}

Este estudo avaliou a resistência à fratura de dentes submetidos ao clareamento interno restaurados com diferentes procedimentos. Quarenta incisivos superiores foram tratados endodonticamente e divididos em 4 grupos $(n=10)$ : G1- restaurados com resina composta (RC), G2- clareados com peróxido de hidrogênio $(\mathrm{PH}) \mathrm{e}$ restaurados com o RC, G3- restaurado com RC e pinos de fibra de vidro ( $\mathrm{RC}+$ pinos) e G4- clareados e restaurados com $\mathrm{RC}+$ pinos. O PH foi aplicado na superfície vestibular e câmara pulpar 3 vezes por sessão, por 2 sessões com intervalo de 7 dias entre elas. Dez dentes hígidos adicionais foram submetidos a teste fratura (padrão ouro). A resistência à fratura $(\mathrm{kN})$ foi determinada em máquina Instron. Os dados foram analisados por Análise de Variânica e teste de Tukey-Krammer $(\alpha=0,05)$. Os dentes não tratados (padrão ouro) apresentaram a maior resistência à fratura $(0,43 \pm 0,16)(\mathrm{p}$ $<0,05)$. Os dentes restaurados com RC (G1) apresentaram a menor resistência à fratura $(0,23 \pm 0,11)(\mathrm{p}<0,05)$. Os dentes clareados e restaurados com RC (G2) $(0,26 \pm 0,10)$, restaurado com $\mathrm{RC}+$ pinos (G3) $(0,31 \pm 0,17)$ e os clareados e restaurados com $\mathrm{RC}$ + pinos $(\mathrm{G} 4)(0,33 \pm 0,12)$ apresentaram valores intermediários, ora semelhantes ao do grupo com o maior valor, ora similares ao grupo de valores mais baixos. Pode-se concluir que os dentes submetidos ao clareamento interno podem ser restaurados com apenas resina composta.

\section{REFERENCES}

1. Plotino G, Buono L, Grande NM, Pameijer CH, Somma F. Nonvital tooth bleaching: a review of the literature and clinical procedures. J Endod 2008;34:394-407.

2. Wetter NU, Barroso MCS, Pelino JEP. Dental bleaching efficacy with diode laser and LED irradiation: an in vitro study. J Clin Laser Med Surg 2004;35:254-258.

3. Oliveira DP, Teixeira ECN, Ferraz CCR, Teixeira FB. Effect of intracoronal bleaching agents on dentin microhardness. J Endod 2007;33:460-462.

4. Chng HK, Yap, AUJ, Wattanapayungkul P, Sim CPC. Effect of traditional and alternative intracoronal bleaching agents on microhardness of human dentine. J Oral Rehabil 2004;31:811-816.

5. Kawamoto K, Tsujimoto Y. Effects of the hydroxyl radical and hydrogen peroxide on tooth bleaching J Endod 2004;30:45-50. 
6. Sulieman M, Addy M, Mcdonald E, Rees JS. A safety study in vitro for the effects of an in-office bleaching system on the integrity of enamel and dentine. J Dent 2004;32:581-590.

7. Cavalli V, Giannini M, Carvalho RM. Effect of carbamide peroxide bleaching agents on tensile strength of human enamel. Dent Mater 2004;20:733-739.

8. Tam IE, Kuo VY, Noroozi, A. Effect of prolonged direct and indirect peroxide bleaching on fracture toughness of human dentin. J Esthet Restor Dent 2007;19:100-109.

9. Pobbe PO, Viapiana R, Souza-Gabriel AE, Marchesan MA, SousaNeto MD, Silva-Sousa YT et al.. Coronal resistance to fracture of endodontically treated teeth submitted to light-activated bleaching. J Dent 2008;36:935-939.

10. Soares PV, Santos PCF, Martins LRM, Soares CJ. Influence of restorative technique on the biomechanical behavior of endodontically treated maxillary premolars. Part I: Fracture resistance and fracture mode. J Prosthet Dent 2008;99:30-37.

11. Bonfante G, Kaizer OB, Pegoraro LF, Valle AL. Fracture resistance and failure pattern of teeth submitted to internal bleaching with $37 \%$ carbamide peroxide with application of different restorative procedures. J Appl Oral Sci 2006;14:247-252.

12. Fokkinga WA, Kreulen CM, Le Bell-Ronnlof AM, Lassila LV, Vallittu PK, Creugers NH. In vitro fracture behavior of maxillary premolars with metal crowns and several post-and-core systems. J Oral Sci 2006;114:250-256.

13. Yamada Y, Tsubota Y, Fukushima S. Effect of restoration method on fracture resistance of endodontically treated maxillary premolars. Int J Prosthod 2004;17:94-98.

14. Coelho RA, Oliveira AG, Souza-Gabriel AE, Silva SRC, SilvaSousa YTC, Silva RG. Ex-vivo evaluation of the intrapulpal temperature variation and fracture strength in teeth subjected to different external bleaching protocols. Braz Dent J 2011;22:32-36.

15. Attin T, Muller T, Patyk A, Lennon AM. Influence of different bleaching systems on fracture toughness and hardness of enamel. Oper Dent 2004;29:188-195.

16. Khoroushi M, Feiz A, Khodamoradi R. Fracture resistance of endodontically-treated teeth: Effect of combination bleaching and an antioxidant. Oper Dent 2010;35:530-537.

17. Pontius O, Hutter JW. Survival rate and fracture strength of incisors restored with different post and core systems and endodontically treated incisors without coronoradicular reinforcement. J Endod 2002;28:710-715.

18. Gonçalves LA, Vansan LP, Paulino SM, Sousa Neto MD. Fracture resistance of weakened roots restored with a transilluminating post and adhesive restorative materials. J Prosthet Dent 2006;96:339344.

19. Bistey T, Nagy IP, Simó A, Hegedus C. In vitro FT-IR study of hydrogen peroxide on superficial tooth enamel. J Dent 2007;35:325-330. 